\title{
Functions and Sales Arguments in Spanish Advertising. A Study on Female Representation
}

\author{
Silvia Vega Saldaña ${ }^{1}$, Daniel Barredo Ibáñez ${ }^{2}$, Carmen Lasso de la Vega ${ }^{1} \&$ Ana Merchán Clavellino ${ }^{1}$ \\ ${ }^{1}$ University of Cádiz, Cádiz, Spain \\ ${ }^{2}$ Universidad del Rosario, Bogotá, Colombia \\ Correspondence: Daniel Barredo Ibáñez, School of Human Sciences, Universidad del Rosario, Bogotá, Colombia.
}

Received: April 12, 2018 Accepted: April 26, 2018 Online Published: May 15, 2018

doi:10.5539/res.v10n3p1 URL: https://doi.org/10.5539/res.v10n3p1

\begin{abstract}
Advertising is responsible for developing part of the contemporary imaginaries, which tend to be imposed as referential frameworks, especially for strategic groups such as those embodied by young people. In this regard, in the following article we present the results of a study in which we evaluated 1520 images published in advertisements from the main Spanish high-end women's magazines (Cosmopolitan, Elle, Glamor, Telva and Vogue). The results in these publications highlight the presence of a restrictive body type for women, which imposes canons of beauty where thinness and slenderness prevail, and to which physical qualities are associated such as white ethnicity, light eyes tonalities, dark or light hair with a length between the shoulders and the chest, a palpable youth and extreme corporal perfection. And also, a pattern that characterizes women devoid of intellectual roles and arguments to purchase and sell, which is an example of symbolic power and objectification of the female body.
\end{abstract}

Keywords: Cosmopolitan, Elle, Glamour, Telva, Vogue, body plan

\section{Introduction}

Since the dawnof Gender Studies, one of the most recurrent research lines is the analysis of women in the media (Alonso, 2004), both due to the easy access to sources as well as for the theoretical utility attributed to helping to erode male symbolic power (Galarza, Cobo \& Esquembre, 2016). The research on which this article adheres to emerges from this line, which addresses the examination and confrontation of two dimensions involving feminine images in advertising: the corporeal and the functional, through which the model of feminine beauty to which the contemporary woman should aspire to is established and divulged, along with the arguments and roles to purchase and sell to which they can aspire. And it is that advertising -as a commercial tool anchored to high-end women's magazines-, delimits and legitimizes what it means to be a woman in each historical period (Gallego, 1990).

This representation starts from a concept of beauty interpreted subjectively (Almela, 2004), but anchored to patterns established by the collective imagination (Baeza, 2000), through which groups are recognized and interact in a sociocultural construction (Behar, 2010). The aforementioned imaginaries forge the social context in which each individual grows; for this reason, researchers such as Volpe, Ramírez \& Novo (2007) consider that beauty or attractiveness that a person may or may not have will be perceived in the same way by different observers, even if they differ in age, sex or culture. In this regard, when in this study we make reference to beauty, we will focus on the material and tangible that corresponds to the corporeal. Which is that, beauty, considered as the main concern and ambition of women (Garrido, 2007), is a stereotype fostered by the media ad nauseum (Gallego, 1990). It is true that beauty, rather than as an inclusive and integrating notion, is taken as an alibi to promote the consumption of numerous products and services, which offer solutions and responses to the supposed accomplishment of women. From this angle, women long to resemble advertising models (Gómez, 2016), and have a perfect body, because the feminine is accomplished through the material, so social success depends on achieving a physique close to the one that insufflates the imaginary.

\section{Defining Western Beauty in High-End Women's Magazines Advertising}

The canons of beauty are constituted as a set of traits or attributes constructed by a society and described within a certain culture (Behar, 2010). In the Western case, the female body plan starts from a set of aesthetic features or attributes, whose pillars approximate the notions of being "white, young, and ectomorph" (Pérez-Gauli, 2000, p.18). Overall, the media and advertisement appropriate these prototypical characteristics (Gómez de Travesedo, 2016), and exalt as the ideal a slender and tall, fibrous woman with soft, tanned, smooth skin where her eyes and lips stand out due to their size and perfection, 
with a subtle nose, striking measures, firm and thin abdomen as well as legs and buttocks, and full breasts, without forgetting their hair, which is shiny, silky and full of luminosity, a perfection that is linked to the youth that these models show. Thus, the aesthetic canon consists of a sum of bodily qualities that are invariably repeated, within which, facial aesthetics stands out first and foremost, as the face is considered a fundamental part of the human body because it concentrates the substantial features used when making a description of a person. In this line, Cáceres \& Díaz (2008) used ethnicity as an indicator to understand that the expressive use of the body should be studied based on physical features, highlighting among these the ethnic group, which is responsible for introducing a certain skin and hair color. In this regard, in a classic study, Macias (1909) stressed the importance of skin color throughout history, listing four types of races: white, yellow, copper and black, at the same time that he exposed the problem of the variation of skin coloration in response to displacements and climate changes to which an individual was exposed. And this is due to the fact that skin tonality is one of the first physical characteristics that the human being perceives when in contact with another, and has been a historically physical discriminatory element (Álvarez, 2008). Following the research of Cáceres \& Díaz (2008), hair tonality is also of great importance, given that it is an element that characterizes women and is an indicator of their femininity. Furthermore, this aspect helps to evaluate the process of masculinization of women that began in the late nineteenth and early twentieth centuries (Febrer, 2009). From that moment, gradually women began to change their way of dressing (Rodrigues, 2010), using pants, suits or short hair as symbols of their newly found independence, and thus approaching the businessman aesthetic. The hair, then, is positioned as a feminine emblem, so much that in some countries like Paraguay it is used as a punishment against indigenous women, since cutting it entails the total loss of their feminine identity. Finally, taking into account the so-called "cultural sub-codes" (Boscán \& Medoza, 2004, p.82) predefined by the historical and cultural conventions of society, the tonality of women's eyes stands out within the aesthetic canon. But curiously, the fulfillment of a woman with the proposed ideal of beauty is achieved thanks to an intangible asset, such as youth, which is synonymous with beauty (Gallego, 1990), and a miraculous gift women must strive for.

\section{Feminine Role and Argumentation at the Service of Advertising}

Historically, and because of the prevalence of a patriarchal role, some aspects that have an impact especially in the public sphere have in general been identified with men such as the ability to discern, decide and reflect, aggression, personal effort, professional success, conquest, competitiveness or risk, among others. On the other hand, women have been assigned other capacities especially in the private sphere, and that are redirected towards their capacity to love such as motherhood, caring for others, intuition, submission or selflessness. These abilities constitute a daily exercise of symbolic power exercised against women (Galarza, Cobo \& Esquembre, 2016), whose expectations and aspirations are restricted. These sources of inequality are frequently reproduced in the media; there are many examples of this. To name one of them, Piñeiro (2010) has identified residues of this violence in radio advertising, where "a deep voice is associated with manliness, serenity, credibility, security, maturity and power" (p. 3), compared with a feminine voice which is more intuitive, seductive and subtle. In its already classic work, McArthur \& Resko (1975) concluded that female figures were less likely to appear as possessing scientific knowledge. This assessment, published almost five decades ago, seems to still be partially valid: only three out of ten researchers in the world are women (El Universal, 2018, 9 February). The problem lies in the fact that, from the advertising distributed by the media, an ideal testimony is given to society, social prototypes are established, roles are defined, a vitiated learning of intolerant attitudes or stereotypes that represent women lacking authority and technical or specialized arguments is set, leaving them displaced - as explained by Berganza \& del Hoyo (2006) -, to a position as subordinate consumers and in need of advice, help and information. In this duality of arguments differences can be seen even in the quality of tone used by men or women (del Moral, 2000); while the female image will point to a more colloquial dialogue, the image of man -characterized by his expertise and authority - will be governed by a more austere tone. To which we must add that the male voice acquires a nuance of experience, and the female one will reflect seduction. Berganza \& del Hoyo (2006) delve into this matter and provide two types of roles in advertising: the consumer character versus the authority character, associating to each one a type of purchase and sales arguments; the first one, linked to women, centered on subjective and emotional arguments while the second, relates to men, identified by its objective and intellectual arguments.

These arguments are easily recognizable and palpable because of their traditional and immobile adjudication to men and women, and they extend and consolidate throughout the female spectrum in the advertisement images, which is the object of study around which this paper has been written. 


\section{Objectives}

This study has been drafted based on the general objective of analyzing the body image of women in advertisements published by high-end Spanish magazines: Cosmopolitan, Elle, Glamour, Telva y Vogue. With the interest of achieving this objective, four specific guidelines have been drawn up, which are:

4.1. Identify the corporal parameters of the models in the advertisements, with the purpose of establishing the body plan that is popularized by the proposed magazines.

4.2. Evaluate the purchase and sales arguments that use female images in the advertisement of the indicated magazines.

4.3. Connect these arguments to a certain female body plan.

4.4. Determine the roles adopted by the women that are focus of the advertising images that make up the sample.

\section{Methodology}

The methodology used for this research is non-experimental and transversal, with a descriptive approach. As a technique, we opted for the content analysis, a quantitative technique, whose analysis sheet has been drawn based on the findings of the previous literature and, in particular, on the works of McArthur \& Resko (1975); Balaguer (1985); del Moral (2000); Loscertales (2003); García-Reyes (2003); Ruiz \& Rubio (2004); Berganza \& del Hoyo (2006); Díaz \& Muñiz (2007); Cáceres \& Díaz (2008); Díaz, Muñiz \& Cáceres (2009); Piñeiro (2010); and Gómez de Travesedo (2016). The analysis sheet consisted of three sections: a section of content classification variables, such as the questionnaire and identification number of the advertisement / identification number of the female image or images / product brand / advertised product / advertiser sector / magazine / month / total of advertising insertions throughout 2014. Second, the variables related to the Corporal and Functional dimensions. In the first one, Corporal Dimension, the following aesthetic variables were coined: height / size / somatotype / ethnicity / eye color / hair color / hair length / age segment / body perfection / face perfection. And in the Functional Dimension the parameters that made reference to the: sales argument / nature of the argumentation / function of the female image, were included.

\section{Sampling}

For this research, 1520 female images have been selected, through a non-probabilistic expert selection sampling. The images were obtained from the 5 Spanish high-end women's magazines (Cosmopolitan, Elle, Glamor, Telva and Vogue), which ranked among the top 25 magazines with the most monthly readers, and with the highest average print run and circulation according to the General Media Study (EGM in Spanish) and the Broadcasting Justification Office (OJD in Spanish) throughout 2014, respectively.

\section{Result Analysis}

The first results based on the Body Dimension opened a gap, on which the research was based, in which the following aesthetic parameters prevailed: $92.2 \%$ of the models were perceived to have a size equal to or less than 36 , a fact already pointed out by Salazar (2007), Soley (2010) and Cabrera (2010), among others. Furthermore, 97\% had a height equal to or greater than 170 centimeters. The somatotype detected by excellence with $99.1 \%$ was ectomorph, in agreement with the previous studies of Cáceres \& Díaz (2008). The white ethnic group, with 93.5\%, stood out due to its presence, a result that coincides with that of Pérez-Gauli (2000). Light eyes, with 63.4\%, prevailed to dark ones, which reached 36.6\%. Long hair obtained $85.1 \%$, while light and dark hair tones were almost even, with $44.2 \%$ and $51.8 \%$, respectively and in accordance with the results obtained by Cáceres \& Díaz (2008).

The predominant age segment imposed for women did not exceed 45 years of age, something that Santiso (2001), Díaz, Quintas \& Muñiz (2010), and Furnham \& Paltzer (2011) also perceived. Finally, the model's body and face perfection by far exceeded the established average, offering a minimum of $4.63(\mathrm{SD}=4.63)$ and 4.57 ( $\mathrm{SD}=.674)$, respectively, results that confirm the establishment of this parameter as an inherent quality to the woman's physique in advertisement (Cáceres \& Díaz, 2008). These first results allowed us to infer the possibility that there existed a prevailing body plan in advertising that could be accessed through the analysis of three variables, which were regularly used separately in several previously cited studies: size, height and somatotype. A fact that became plausible when verifying that $91.1 \%$ of female images corresponded to what has been called as strict body plan (PCE in Spanish), in which the models had a size equal to or less than 36 , a height equal to or greater than 170 centimeters, and an ectomorphic somatotype. It should be noted that only $8.9 \%$ of the images collected sustain a non-restrictive body plan (PCNE in Spanish).

Within the aforementioned PCE, the following aesthetic features have been identified: first, the white ethnic group, of which it should be noted that despite there being no statistically significant differences for the ethnic and body plan variables $(\chi 2=1.362 ; p=.243)$, it prevails in the sampling advertising and therefore it is relevant. Second, the light and dark hair tones are associated equally with the PCE $(\chi 2=6.322, \mathrm{p}=.042)$, and it is the dimension involving other colors ( $\mathrm{p}$ $<.05)$, which has been related to the PCNE. Regarding eye color, statistically significant differences were found between 
both patterns $(\chi 2=48.176, p=.000)$, with PCE being related to light eyes. And the models that have exhibited long hair have also obtained statistically significant differences $(\chi 2=13.086, p=.000)$, relating to the PCE. Regarding the age segment, the Chi-square test $(\chi 2=157.721, p=.000)$, pointed out the existence of significant statistical differences in the proportions between both body plans, finding a greater number of young women with PCE. Finally, statistically significant differences were also found between both body plans, both for facial perfection $(U=24276.000, p=.000)$, and for body perfection $(\mathrm{U}=25418.500 ; \mathrm{p}=.000)$. That is, these qualities are associated and accentuated in the PCE when compared to PCNE. This block of results allowed to establish the existence of two canons of beauty in force in the advertising of high-end Spanish women's magazines (see Table 1): Canon 1 - to which young women of size $\leq 36$, a height $\geq 170$ centimeters, ectomorphic somatotype, white ethnicity, light eyes and long hair with a face perfection index of 6.7 points $(\mathrm{SD}=.51)$ and 6.53 points $(\mathrm{SD}=.59)$ for the body. And the second corporal canon obtained, Canon 2 - to which young women of size $\leq 36$, a height $\geq 170$ centimeters, ectomorphic somatotype, white ethnic group, dark eyes and long hair with an index of perfection for the face of 6.57 points $(\mathrm{SD}=.58)$ and 6.37 points $(\mathrm{SD}=.59)$ for the body (Note 1$)$.

Table 1. Distribution of PCE traits, according to the images of the high-end Spanish women's magazines consulted (2014).

\begin{tabular}{|c|c|c|c|c|c|c|}
\hline $\mathrm{PC}$ & Ethnicity & $\begin{array}{l}\text { Eye } \\
\text { Color }\end{array}$ & $\begin{array}{l}\text { Hair } \\
\text { length }\end{array}$ & Age & $\mathrm{N}$ & $\%$ \\
\hline PCE & White & Light & $\begin{array}{l}\text { Medium } \\
\text { length }\end{array}$ & Young & 615 & 56.3 \\
\hline PCE & White & Dark & $\begin{array}{l}\text { Medium } \\
\text { length }\end{array}$ & Young & 269 & 24.7 \\
\hline PCE & White & Light & Short & Young & 94 & 8.7 \\
\hline PCE & $\begin{array}{l}\text { Other } \\
\text { ethnic } \\
\text { group }\end{array}$ & Dark & $\begin{array}{l}\text { Medium } \\
\text { length }\end{array}$ & Young & 52 & 4.8 \\
\hline PCE & White & Dark & Short & Young & 31 & 2.8 \\
\hline PCE & $\begin{array}{l}\text { Other } \\
\text { ethnic } \\
\text { group }\end{array}$ & Dark & Short & Young & 18 & 1.6 \\
\hline PCE & White & Light & $\begin{array}{l}\text { Medium } \\
\text { length }\end{array}$ & Adult & 7 & 0.6 \\
\hline PCE & $\begin{array}{l}\text { Other } \\
\text { ethnic } \\
\text { group }\end{array}$ & Light & $\begin{array}{l}\text { Medium } \\
\text { length }\end{array}$ & Young & 2 & 0.2 \\
\hline PCE & White & Light & Short & Adult & 2 & 0.2 \\
\hline PCE & $\begin{array}{l}\text { Other } \\
\text { ethnic } \\
\text { group }\end{array}$ & Light & Short & Young & 1 & 0.1 \\
\hline
\end{tabular}

Regarding the results that refer to the Functional Dimension, first a general sampling has been carried out to verify what kind of sales argument the female images offered in the printed media in favor of the product they advertised and are associated to. This step was carried out with the purpose of studying what role the model adopts in relation to the product, expert or non-expert, in the eyes of the public. The results found that only three women out of the 1520 female images analyzed were identified in the role of expert and showing a scientific argument, meaning that $99.8 \%$ of the female images were shown as a non-expert role in relation to the advertised product. These data coincides with those obtained by the classic work of McArthur \& Resko (1975), whose conclusions indicated that women are significant and less represented in a role in which they exhibit a scientific argument, a space reserved for the male figure.

In second place, we proceeded to analyze the role assumed by the woman when establishing the purchase argument; for this purpose, the same mechanics as in the case of the sale argument was executed, and therefore, a general sampling was carried out to see what type of purchase argument the female images of the sample offered compared to the advertised product to which they were associated. In this argument, similar results were obtained when three cases were found in which the feminine images offered scientific purchase arguments against the remaining 1517, in which the model relies on 
emotional purchase arguments. These results show that once more the female figure occupies a subordinate place by not being represented as a consistent, rational or objective consumer of the product or service, since its purchase arguments are emotional and respond to the feminine impulse, while men - says Berganza \& del Hoyo (2006) -, use rational argumentation to encourage purchase.

And in third place, the general analysis showed that the most popular role adopted by the models in female images is that of mannequins, with a total of 1073 models that fulfill this function; while those that add value to the advertised product or those that are contemplated as the product itself, hold 392 and 55 female images, respectively. In this regard, Bernárdez (2000) denounces that this type of mannequin woman has a body that he calls "disembodied" (p.67), a body that is not seen for its individual distinguishing qualities but highlighted as a thing or object. And, as the objects they are, they do not even show pores, they are totally perfect and are structurally defined and delimited. To which Abuín (2009) adds that it is common to find young and perfect women employed as an aesthetic claim on which to wear or adorn the advertised product or service. Moreover, this author emphasizes that this type of representation proliferates in the perfumery and cosmetics sector. On the other hand, Rodríguez, Matud \& Espinosa (2008) conclude that male images are not represented as sexual objects, while female ones do occupy these roles since they are considered as sexual objects, and by being portrayed as devoid of life, becoming dolls or mannequins at male service or of that of the product or service advertised. From this perspective, it is important to emphasize that the quintessential role played by the selected sample for this study was that which exhibited the woman as a mannequin.

Once the general data of the Functional Dimension were extracted, the correlation that could exist between both Dimensions was examined in order to find out, first of all, if the body plans would affect the sale argument used by the models. The data proved that despite the prevalence of unscientific argumentation throughout both body plans (in which the PCE achieved $100 \%$ in relation to the argument in which the woman was qualified as non-expert, while the PCNE reached $97.8 \%$ for the same category), an association was established between the PCNE and the expert function that introduces the scientific argumentation, since the Chi-square test showed statistically significant differences between both patterns $(\chi 2=30.83 ; p=.001)$ (Note 2$)$. And, therefore, the role of the woman as an expert in relation to the product was dissociated, and this circumstance was accentuated with the implementation of non-scientific argumentation and the fulfillment of the image of a strict body plan.

Next, we proceeded to the analysis of the purchase arguments used by the female images based on the body plan introduced by the model. The results showed that feminine emotional argumentation prevails in both patterns, while extremely high scores were recorded for PCE and PCNE, 100\% and 99.8\%, respectively. Despite this, the scientific purchase argumentation was related to the PCNE, as it was indicated by the Chi-square test, showing statistically significant differences between both patterns (Note 3$)(\chi 2=30.8, p=.001)$. In this regard, Berganza \& del Hoyo $(2006)$ not only denounced the presentation of a female figure as an irrational consumer but highlighted the identification of women with that of an empty consumer, and that is not objective, deprived of and not having a personal opinion that, far from being their own, is dependent on a masculine one. Through statistical analysis, we found that the role imposed on women when offering a purchase argument is emotional, and that this will be accentuated in cases where the model has a PCE.

And, in third place, we tried to find out if body plans tended to be associated with any of the three previously delimited roles: feminine image converted into the product itself, feminine image used as a mannequin, and feminine image that adds value to the product.

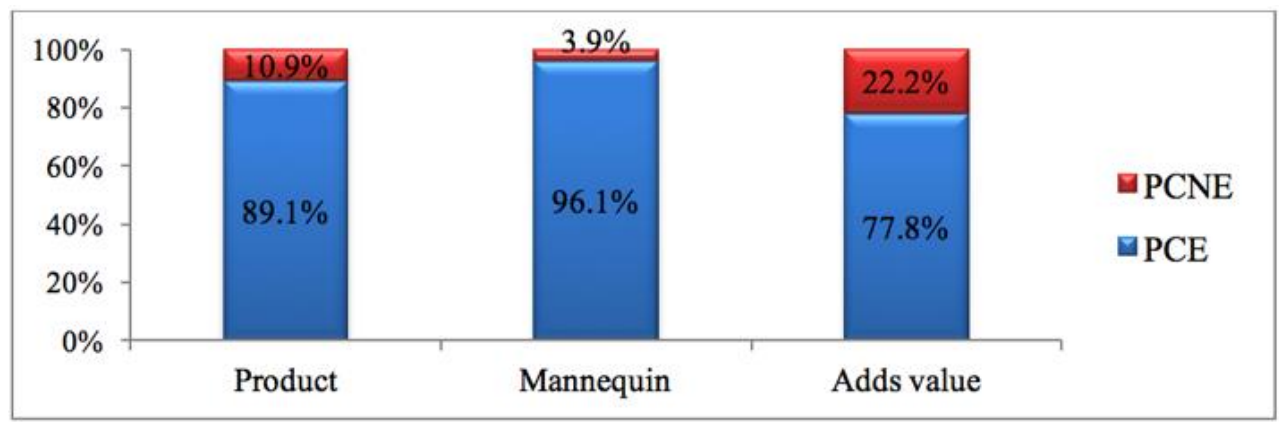

Figure 1. Representation of the female role relating to the product according to body plan, as seen in the images consulted in the high-end Spanish women's magazines (2014). Source: self-made

It can be seen (see Figure 1) that the PCE is related to the female images that in advertising adopt the role of a mannequin, 
data that corroborates the Chi-square test $(\chi 2=118.84, p=.000)$. Likewise, it can be seen that the female images that add value to the product have a greater impact for the PCNE. That is why the results show that advertisers use to display their products or services on mannequin-like women who have a PCE, a trend that is reversed when what they intend to do is to add value to the product or service advertised using female images; in these cases, women who have a PCNE are employed, although as Diaz points out (2007), the general tendency is for the feminine image to provide an aesthetic value, a fact that is feasible in both roles.

Finally, a final analysis showed that all the images belonging to the two canons of beauty previously delimited, introduced unscientific sales arguments in which the model was portrayed in the role of non-expert, and which in all cases also used emotional purchase arguments. Regarding the female role represented based on the product, it can be stated that in Canon 1 it was found that $72.4 \%$ of the models were identified in the role of mannequins, $23.4 \%$ contributed value, and only $3.9 \%$ were perceived in the role of the advertised product. In turn, Canon 2 showed that $71.3 \%$ of the models were identified in the role of mannequins, $24.9 \%$ contributed value, and only $3.8 \%$ were perceived in the role of the advertised product. In line with the research work implemented, both dimensions -corporal and functional- were confronted, which allowed to establish that the feminine images belonging to Canon 1, showed $72.6 \%$ of non-scientific sales arguments, that is, emotional purchase arguments whose function was equivalent to that of a mannequin; 23\%, showed unscientific sales arguments, emotional purchase arguments whose function was to provide value; $3.8 \%$, unscientific sales arguments, emotional purchase arguments whose function was to become the advertised product; and only $0.5 \%$ of the images showed an intellectual argument adding value to the advertisement. The models attached to Canon 2 exhibited $71.3 \%$ as non-scientific sales arguments, emotional purchase arguments whose function was equivalent to that of a mannequin; $24.9 \%$ as unscientific sales arguments, emotional purchase arguments whose function was to provide value; and $3.8 \%$ as non-scientific sales arguments, not finding any image that assumed an expert role regarding the product or resorting to intellectual sales arguments at the time of purchase.

\section{Discussion and Conclusions}

The collective imaginaries assume canons of beauty, which strongly influence the individual interpretation (Baeza, 2000), and impact especially on the individuals growing up. In that regard, we think that the media have a great responsibility in the development of these imaginaries; in our case, we have empirically verified how, through the diffusion of stereotyped images, the advertisements disseminated by high-end Spanish magazines are responsible for reinforcing a restrictive body plan. This plan fosters an aesthetic rigidity of contemporary women, by introducing models of size below or equal to 36 , with a height of 170 centimeters or more, and an ectomorphic somatotype. A body plan, that also covers these publications relegating to a second and third place those aesthetic models not related to it. And that introduces two canons of almost identical beauty that present a white woman, with light eyes, dark or light hair with a length between the shoulders and the chest, young, and of an excellent body perfection. This body plan, from which canons 1 and 2 are derived, implements a prototype of a woman in which there is no room for the scientific or intellectual sales or purchase arguments in relation to the advertised product or service, the feminine being defined by its irrational and emotional character which bears away from the role of expert. And, what is worse, the protagonist of this type of publicity is relegated to a mannequin role, an idealization devoid of intellectual abilities.

We are, therefore, before a case that fits in the notion of symbolic power explained by Galarza, Cobo \& Esquembre (2016), that is, the iconographic use of women, as an object that sustains the maintenance of a patriarchal logic of looting of female freedom, of objectification, and subjection. If the sophisticated woman can only be thin, tall and not excessively intelligent - as proposed by the high-end Spanish magazines studied - this implies that the feminine struggle must focus on the individual, against herself, against her aspirations -considered defects when they are not related to those ideals that the advertisements carelessly foster. Therefore, women are only complete based on the mutilation of their particularities, especially when these differ from the corporal preoccupation; Furthermore, aging is tabooed in this process, considering it more as a disease -which must be prevented through the consumption of creams, cosmetics and other artifacts and solutions-, than as a stage of life.

In this way, under the pretext of beauty, media such as those analyzed disseminate the ideal of unattainable beauty, with which they actively stimulate dissatisfaction with the impossibility of carrying out strictly designed bodily proposals. And anxiety, as is well known, is a great ally for the promotion of the sale of products. But it is also responsible for the eating disorders that Behar (2010) explains, such as anorexia or bulimia, especially among younger women. 


\section{References}

Abuín, V. N. (2009). Publicidad, roles sociales y discurso de género. En Actes de Congénere: La representació de gènere a la publicitat del segle XXI, 1-12, Universitat de Girona. Retrieved from http://www3.udg.edu/publicacions/vell/electroniques/congenere/ponencies/02_publicidad_role ssociales_discurso.pdf

Almela, R. (2004). La imagen actual en la intersección del arte y la publicidad. En III Simposio de comunicación: Arte y Publicidad en Comunicación. Retrieved from http://www.criticarte.com/Page/file/art2004/ArteyPublicidadPrint.html

Alonso, A. J. (2004). Mujeres en los medios, mujeres de los medios. Barcelona: Icaria.

Álvarez, R. S. (2008). Esclavitud y cuerpos al desnudo. La sexualidad y la belleza de la mujer negra. Revista Sexología y Sociedad, 14(37), 36-39.

Baeza, M. A. (2000). Los caminos invisibles de la realidad social: ensayo de sociología profunda sobre los imaginarios sociales. Santiago de Chile: Ril Editores.

Balaguer, M. L. (1985). La mujer y los medios de comunicación.: el caso de la publicidad en televisión. Málaga: Arguval.

Behar, R. (2010). La construcción cultural del cuerpo: El paradigma de los trastornos de la conducta alimentaria. Revista Chilena de Neuro-Psiquiatría, 48(4), 319-334.

Berganza, M. R., \& del Hoyo, H. M. (2006). La mujer y el hombre en la publicidad televisiva: imágenes y estereotipos. Revista de estudios de comunicación, Zer, 21,161-175.

Bernárdez, A. (2000). Cuerpos imaginarios: ¿exhibición o encubrimiento de las mujeres en la publicidad? Cuadernos de Información y Comunicación, 5, 67-78.

Boscán, J. P., \& Mendoza, M. I. (2004). Análisis semiótico de la publicidad de perfumes. Opción, 20(45), 75-93.

Cabrera, O. Y. (2010). El cuerpo femenino en la publicidad. Modelos publicitarios: entre la belleza real, la esbeltez o la anorexia. Icono, 14 (8), 223-243.

Cáceres, M. D., \& Díaz, S. P. (2008). El uso del cuerpo en la publicidad de marcas de moda de lujo. Actas y memoria final: Congreso Internafional Fundacional AE-IC.

http://www.ae-ic.org/santiago2008/contents/pdf/comunicaciones/108.pdf

Del Moral, M. E. (2000). Los nuevos modelos de mujer y hombre a través de la publicidad. Comunicar, 14, 208-217.

Díaz, S. P., \& Muñiz, C. (2007).Valores y estereotipos femeninos en la publicidad gráfica de las marcas de moda de lujo en España. Zer, 23, 75-94.

Díaz, S. P., Muñiz, C., \& Cáceres, Z. D. (2009). Consumo de revistas de moda y efectos en la autopercepción del cuerpo de mujeres: un estudio comparado entre España y México desde la Tercera Persona. Comunicación y Sociedad, XXII(2), 221-242.

Díaz, S. P., Quintas, F. N., \& Muñiz, C. (2010). Cuerpos mediáticos versus cuerpos reales. Icono 14, 8(3), 244-256.

El Universal. (2018, February 9). En el mundo, menos de 30\% de los investigadores son mujeres. Retrieved from http://www.eluniversal.com.mx/ciencia-y-salud/ciencia/en-el-mundo-menos-de-30-de-los-investigadores-son-muje res

Febrer, N. (2009). Arte de género: cuerpos profanados y fenómenos andróginos. Observaciones filosófica, 9. Retrieved from http://www.observacionesfilosoficas.net/artedegenero.htm

Furnham, A., \& Paltzeer, S. (2011). The portrayal of men and women in British television advertisements: A review of 7 studies published over a 12 year period. Journal Mass Communication Journalism, 1(1), 1-6.

Galarza, E., Cobo, R., \& Esquembre, M. (2016). Medios y violencia simbólica contra las mujeres. Revista Latina de Comunicación Social, 71, 818-832.

Gallego, J. (1990). Mujeres de papel. De Hola a Vogue: La prensa femenina en la actualidad. Barcelona: Icaria.

García-Reyes, I. (2003). La mujer, sujeto y objeto de la publicidad en televisión. (Doctoral dissertation). Universidad Complutense, Madrid, España.

Garrido, R. M. (2007). Los rasgos temáticos y de estilo propios del periodismo de servicio en las revistas femeninas de alta gama. (Doctoral dissertation). Salamanca, Universidad Pontificia de Salamanca.

Gómez de Travesedo, R. (2016). La representación de la mujer en las revistas femeninas comerciales españolas de alta 
gama durante la crisis. (Doctoral dissertation). Málaga, Universidad de Málaga.

Loscertales, F. (2003). "El lenguaje publicitario: estereotipos discriminatorios que afectan a las mujeres". En Ramírez, M. del M. (Coord.). Medios de comunicación y violencia contra las mujeres, 95-110. Sevilla: Instituto Andaluz de la Mujer y Fundación Audiovisual de Andalucía.

Macías, C. (1909). Caracteres étnicos en general. Anales del Instituto Nacional de Antropología e Historia, IV, 171-182.

McArthur, L. Z., \& Resko, B. G. (1975). The portrayal of men and women in American TV commercials. Journal of Social Psychology, 97, 209-220.

Pérez-Gauli, J. C. (2000). El cuerpo en venta. Relación entre arte y publicidad. Madrid: Cátedra.

Piñeiro, M. T. (2010).Voces femeninas en la publicidad radiofónica española. Una aproximación a su presencia y utilización desde la perspectiva del análisis de contenido. Razón y Palabra, 74. Retrieved from http://www.razonypalabra.org.mx/N/N74/VARIA74/43PineiroV74.pdf

Piñeiro, M. T. (2010). La utilización de la voz femenina como autoridad en la publicidad radiofónica española. Pensar en la Publicidad, IV(2), 191-214.

Rodríguez, C., Matud, P., \& Espinosa I. (2008). Género y publicidad en la prensa diaria. Questiones Publicitarias, 1(13), $1-9$.

Ruiz, G. M., \& Rubio Algarra, J. (2004). La influencia de los medios de comunicación en las imágenes femeninas. Actitudes, hábitos y comportamientos de las mujeres con respecto a la belleza y el cuerpo. Clepsydra, 3, 89-107.

Salazar, M. Z. (2007). Imagen corporal femenina y publicidad en revistas. Revista de Ciencias Sociales (Cr), II(116), 71-85.

Santiso, S. R. (2001). Las mujeres en la publicidad: análisis, legislación y aportaciones para un cambio. Acciones $e$ Investigaciones Sociales, 13, 43-60.

Soley, B. P. (2010). Cuerpos ideales. Una aproximación interdisciplinaria al estudio de las modelos de moda. Quaderns, 26, 107-134.

Volpe, Ch. R., Ramírez, O. M., \& Novo, T. A. (2007). El ojo hermoso. Cirugía Plástica Ibero-Latinoamericana, 33(2), 79-90.

\section{Notes}

Note 1: It should be noted that the variable that refers to hair color has been eliminated from this last statistical operation based on the results obtained, in which none of the items that compose it (dark and light) has a significant percental difference, as in the case of ethnicity; to which it must be added that these items are distributed and related equally in both PCs and is therefore present.

Note 2: Corrected by Fisher's exact statistic.

Note 3: Corrected by Fisher's exact statistic.

\section{Copyrights}

Copyright for this article is retained by the author(s), with first publication rights granted to the journal.

This is an open-access article distributed under the terms and conditions of the Creative Commons Attribution license (http://creativecommons.org/licenses/by/4.0/). 